\title{
"EnoAventura na Serra Catarinense" - the game: Rural tourism as a fortress to leverage enotourism and winemaking education in the region with the lowest human development index in the state of Santa Catarina, Brazil
}

\author{
M. de Vasconcellos Dullius ${ }^{1}$, I.R. da Silva ${ }^{2}$, and B.R. Santa Rosa ${ }^{1}$ \\ ${ }^{1}$ Instituto Federal de Educação, Ciência e Tecnologia de Santa Catarina, Oenology professor, Departamento de Ensino, \\ Pesquisa e Extensão, Câmpus Urupema, 88625-000 Rua do Conhecimento, s/n, Urupema, Santa Catarina, Brazil \\ ${ }^{2}$ Instituto Federal de Educação, Ciência e Tecnologia de Santa Catarina, Academic student from Technology in Viticulture and \\ Oenology, Câmpus Urupema, 88625-000 Rua do Conhecimento, s/n, Urupema, Santa Catarina, Brazil
}

\begin{abstract}
In the state of Santa Catarina (SC), south of Brazil, extends the region of "Planalto Catarinense", which is divided into 18 municipalities comprised within the geographic limits of the "Serra Catarinense". The vine, in the "Planalto Catarinense" is the second fruit cultivation of commercial relevance, and it is boosting the tourism in the region. Exploring the enotourism is perhaps one of the most promising attractions connecting the incipient wine region with the unique landscape. With the purpose of contributing to the enotouristic complex cluster, this work aimed at creating a board game highlighting featured tourist points of each of the 18 municipalities of "Serra Catarinense". The game presents itself as a playful tool that brings concepts of viticulture and oenology and incorporates the tourist and gastronomic attributes of mountainous region, notoriously lacking in economic development strategies that generate employment, income and life improvement. The game is a bet and it seeks to offer new insights into the classic themes surrounding grape and wine production, professional education and promising economic development for the "Serra Catarinense".
\end{abstract}

\section{Introduction}

Brazil has the privilege of possessing the most diversified landscapes. It is in the state of Santa Catarina (SC), in the southern region of the country, that extends to the region of "Planalto Catarinense", where, in the upper eastern part, the administrative territory is divided into 18 municipalities comprised within the geographic limits of the "Serra Catarinense" [1], in spite of particularities marked in their history and/or geography, have among themselves common characteristics of this physiographic region and that, in a very curious way, hardly have anything to do with the most emblematic symbols by which Brazil is known for the rest of the world. Currently, the "Planalto Catarinense" stands out as being the largest region producing grapes and wines in SC, although viticulture and oenology are relatively recent in 18 mountainous municipalities [2], which preserve in common the fact that are the poorest region in that state [3]. The result of a cut-off relief and rock formations that are between 800 and 1.800 meters above sea level, the predominant natural landscape is of high-altitude fields and mixed ombrophilous forests [4]. The proximity to the Atlantic coastline maintains high humidity in the only region of Brazil that presents temperate oceanic climate (Cfb) according to Köeppen (1936) classification [5]. Temperatures are mild for most of the year and there is usually enough nightly cold to develop temperate crops. It is no wonder that fruit trees such as apple, peach, plum, quince and vine grow well in this region [6]. The vine, in the "Planalto Catarinense" is the second fruit cultivation of commercial relevance, having reached in the last years an area of production of approximately 400 ha, and also allowed the establishment in the vicinity of the municipality of São Joaquim (in the center of the mountainous region) of 14 wine-growing enterprises in the last 20 years [2], which have the challenge of changing the social reality of the region. The incipience of the region as a wine cellar associated with the natural beauties of the region and absolutely differentiated when compared to the rest of Brazil, meant that the targeting of companies that bet on wine as business for the development of the region incorporated the tourist and gastronomic complex to ensure the success of its activities [7]. The tourist routes show the exuberance of a landscape of cold weather and the typical gastronomy of the local colonization. Although the attractions are not few, the municipalities, extensive geographically, and little territorially occupied, still have much to reveal to the enotourist who decides to venture through unconventional Brazilian landscapes.

\subsection{Objectives}

With the purpose of contributing to the enotouristic complex cluster of the mountainous region and spreading the world of incipient wine in the regions of higher altitude of SC, this work aimed at creating a board 


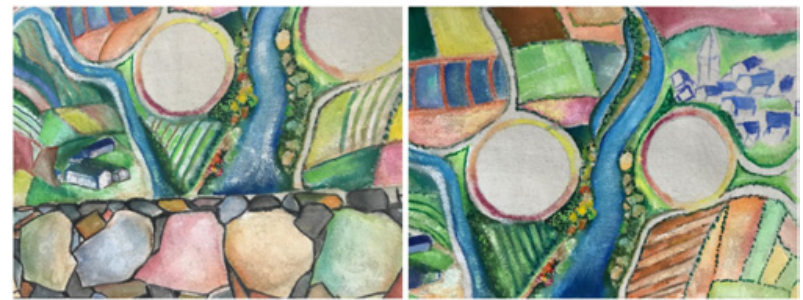

Figure 1. Spots from the board game evidencing the "taipa" in the bottom of the left image.

game highlighting featured tourist points of each of the 18 municipalities of Serra Catarinense.

\section{Materials and methods}

The game, developed by TOenologY, a junior enterprise incubated within the Instituto Federal Santa Catarina (IFSC), presents itself as a playful tool that brings concepts of viticulture and oenology and incorporates the tourist and gastronomic attributes of mountainous region, notoriously lacking in economic development strategies that generate employment, income and life improvement. The game was developed to commemorate the $30^{\text {th }}$ anniversary of Urupema, the host municipality of the aforementioned Institute, in which there are technical educational levels for the generation of professionals who will work with viticulture and winemaking, and with all derivations (enogastronomy, enotourism) that this activity is capable of promising. The game also seeks to offer new insights into the classic themes surrounding grape and wine production, professional education and also promising economic development for "Serra Catarinense". The game was set to allow players exploring the experience of growing vines and making wine in "Serra Catarinense" at the same time.

\subsection{Leveraging information}

\subsubsection{Placing enouturism in the Serra Catarinense}

First, the 18 municipalities belonging to "Serra Catarinense" microregion were researched with the purpose of showing the particularities that could be used somehow as a strong fortress and highlight the cities itself. A lot of typical fairs, festivals, religious events, representative monuments, and popular legends were studied for confirming veracity and, those who were considered most representative of the cities or that could set dynamism for the game were picked for building the cards named "Enoturismo". Those cards are action cards in the game that when picked by the player allow development on enoutourism in the mentioned area.

The board contains a representation of the natural landscape with the small municipalities and peculiarities inherent to the "Serra Catarinense". Spread randomly, there are 18 vineyards with circular areas suitable for the placement of small cards ("tazos") which are distributed at the beginning of the game and with the verse upwards and will constitute the complete enotourism cluster of the "Serra Catarinense".

The perimeter of the board presents the representation of a stone wall typical of the region, known as "taipa". The first examples of this wall arose at the time of the

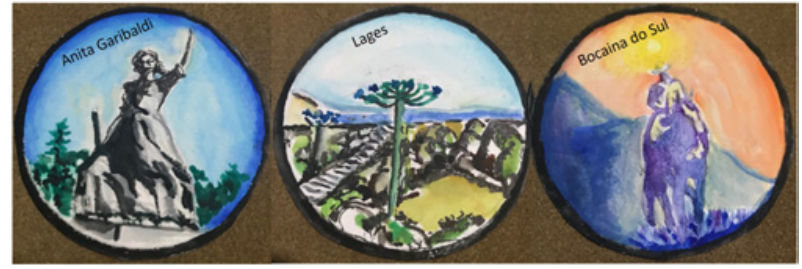

Figure 2. Examples of "tazos" from tree different municipalities indicated in the card disc.
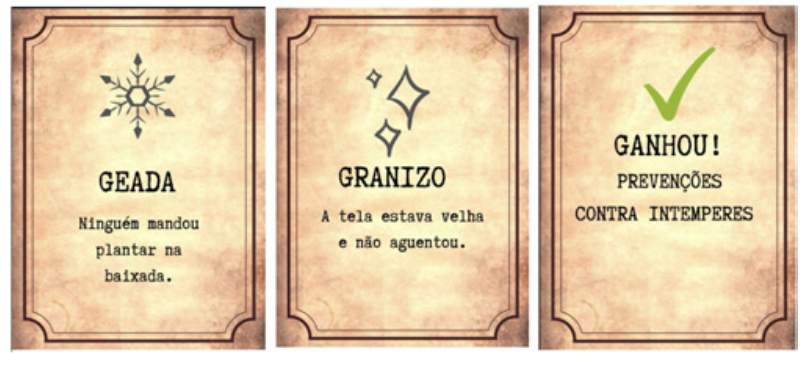

Figure 3. Exampling the occurrence of bad weather and a card that allow a solution on it.
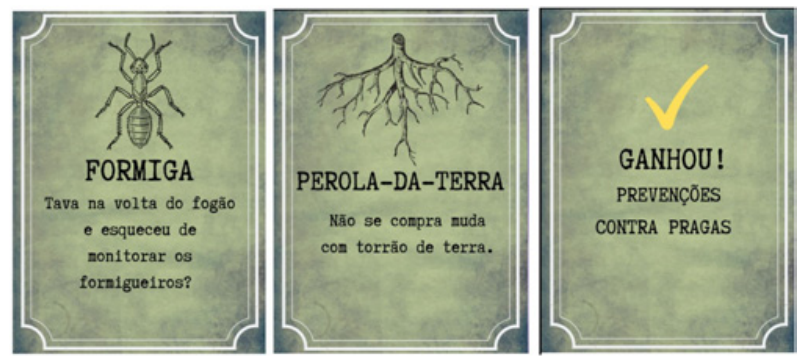

Figure 4. Exampling the occurrence of crop plagues and a card that allow a solution on it.

colonization of the Brazilian territory. Build by the slaves and crossing the natural landscape, the "taipas" served as demarcations of specific areas for resting the cattle that were taken from the south and directed towards the southeast of Brazil. Men and animals that travelled along these mountain routes were known in History as "tropeiros" and deeply marked the habits of life and culture of this southern region of the country.

\subsubsection{Growing vines in the "Serra Catarinense"}

The primary purpose of the game is to grow vines. For getting it so, two grape varieties which are having detached performance in the "Serra Catarinense" microregion were elected to represent viticulture. A white French variety, which is sauvignon blanc and a red Italian variety, which is sangiovese were the ones elected. The versatility and the range of those grapes turned them on the elected grapes for representing "Serra Catarinense".

The players have the opportunity of acquiring lands for growing grapes in the 18 municipalities that set the "Serra Catarinense" microregion. The land is picked randomly, and when chosen, the player turns on the "tazo" that is placed besides the land. The "tazo" indicates which of the cities belongs the land. It will also be responsibility of the player to develop the enotourism in that place. 


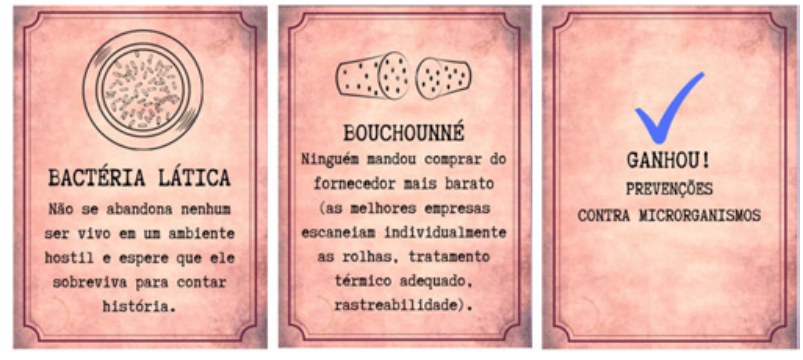

Figure 5. Exampling the occurrence of microorganism contamination and a card that allow a solution on it.

Table 1. Possibilities of wine and its occurrence (\%).

\begin{tabular}{|c|c|}
\hline Wine & Occurrence (\%) \\
\hline $100 \%$ sangiovese & 7.69 \\
\hline 25\% sangiovese: $75 \%$ sauvignon blanc & 30.77 \\
\hline $50 \%$ sangiovese: $50 \%$ sauvignon blanc & 23.08 \\
\hline $75 \%$ sangiovese: $25 \%$ sauvignon blanc & 30.77 \\
\hline 100\% sauvignon blanc & 7.69 \\
\hline
\end{tabular}

\subsubsection{Making wine in the "Serra Catarinense"}

The second purpose of the game is to make wine. The wines can be varietals or blends, and, of course, all of them must be made from the two varieties chosen to represent the "Serra Catarinense" viticulture. Statiscally, five possibilities are allowed in the game, all shown in Table 1 with the correspondent occurrence $(\%)$.

All the time the player is placed in the spot named "viticultura" he/she is able to pay for growing vines. The kind of variety it will be planted is randomly defined by rolling the dice.

\subsubsection{The uncontrolled action and the management in the game}

In the course of the game, uncontrolled situations in the vineyard, related to inclement weather can occur.

When the player picks a card, it is mandatory paying for solving problems. Other situations that can occur are related to administrating the business of vine growing or wine making.

Those situations are linked to technical knowledge but in a simplified message, which has the purpose to entertain and to provide pertinent information about viticulture and oenology. A lot of local problems were compiled on those cards with the intention of stablishing to players a general idea of how particular can be growing vines and making wines in the "Serra Catarinense" region.

All investments in properties and development of enotourism are available through managing money. Nine different monetary notes among $\$ 1$ and $\$ 1000$ that receive the name of the religious entities in the most different civilizations along the History allow the mechanism of buying properties and making inputs in the vine/wine business.

The enotourism activities involve vineyards picnics, the possibility of parties and marriages in the crops, biking

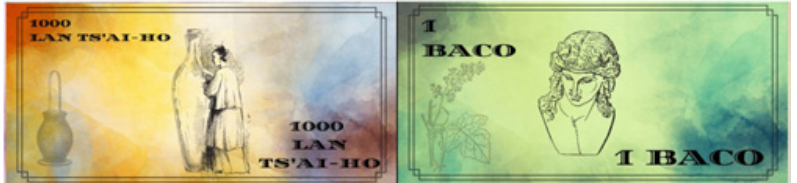

Figure 6. Exampling the monetary notes of the game.

on vine routes, harvesting grapes in season, marathoning in the fields, collecting honey, mushrooms or other native products among the vineyards areas, ballooning above the vineyards, watching native birds and animals among the vineyards areas, climbing typical trees and watching landscape, night harvesting grapes, among others.

\subsubsection{The goal of the game}

There are 15 goals in the game that ensemble making wine and developing the enotourism. The degree of difficulty for making each wine are considered for stablishing the goals. Yet the enotourism development is completely dependent on rolling the dice.

\section{Final considerations}

The only Santa Catarina microrregion that does not have a prominent pole in the technological sector is the one that correspond to "Serra Catarinense" [8]. Considering also the territorial extension, the total GDP (gross domestic product), GDP per capita and population density, it is observed that the mentioned region has disadvantages in all their numbers: with land area just smaller than the "Oeste" microregion of SC state, presents the lowest total GDP, the lowest GDP per capita and the lowest population density, of all the microrregions of Santa Catarina. Besides that, the "Serra Catarinense" exhibits low occupancy rate, and is characterized by essentially primary activities and minimal technology inputs. Economic indicators are not enough, nor are social indicators better. Deficiencies in education are obstacles to the possibilities of professional advancement, and, generally, less educated populations end up being absorbed as cheap labour for activities of low intellectual demand and, consequently, of low remuneration. In the last 50 years, it was possible to observe the insertion of the fruit activity in the old productive matrix of "Serra Catarinense" based, traditionally, on the extension cattle production and the extractive exploitation of the wood. The cultivation of apple trees is notably the most important to the mountainous region, in São Joaquim, Bom Jardim da Serra, Bom Retiro, Rio Rufino, Urubici and Urupema concentrated about 400 tons of apple produced in SC, which corresponds to, approximately $40 \%$ of the national production [4]. It was from the year 2000 that the wine business began to gain space in the "Serra Catarinense". Many investors believed the good productive results of cultivation of other temperate fruit trees (apple, pear, peach) [6], and, encouraged by the opportunity of investment in the region, backed the cultivation of the vine in Santa Catarina altitude fields. The forefront had been boosted in part by the reconfiguration of world winemaking, which has encouraged the cultivation of fine 
grapes and the production of wines in regions of high altitude since the end of the last century. Examples of this altitude viticulture are crops near Tarija, Bolivia; of the Calchaquí Valley in Salta, Argentina; of Arequipa, Peru; of the Diqing Plateau, in Yunnan Province, China and also in Santa Catarina, Brazil [9]. The combination of type of soil volume average rainfall, average annual temperature and especially the significant thermal amplitude offer suitable conditions for the obtaining of fine quality wines and competitive in the current wine market, and although the enterprises in the region are recent, it is time to make known to the world a little of what has been developed in terms of viticulture in the Santa Catarina state. In the hills of Santa Catarina, the tourist experience is, above all, rural endowed with primary attractions in the form of important and well-publicized landscaping and climatic conditions the cold is usually sought, usually in the expectation of snow - and it is also linked to socio-cultural aspects and regional history. "EnoAventura na Serra Catarinense" - the game: rural tourism as a fortress to leverage enotourism and winemaking education in the region with the lowest human development index in the state of Santa Catarina, Brazil, is an interactive, educational and technical game that combine all the elements of entrepreneurship for the vitiviniculture in the "Serra Catarinense".

\section{References}

[1] IBGE. Available on <https://biblioteca.ibge. gov.br/visualizacao/livros/liv55077.pdf $>$. Access in 04/27/2019

[2] ACAVITIS, In: IV Seminário de Enologia e Turismo: vinho e identidade cultural, Instituto Federal Santa Catarina, 06 e 07 de dezembro de 2018 (2018)

[3] IBGE. Available on $<$ https://cidades.ibge.gov . $\mathrm{br} / \mathrm{brasil} / \mathrm{sc} /$ urupema/pesquisa/40/30277>. Access in: 10/31/2017

[4] IBGE, Available on: <ftp://ftp.ibge.gov . br/Producao_Agricola/Levantamento_ Sistematico_da_Producao_Agricola_\% 5Bmensal\%5D/Fasciculo/1spa_201702.pdf >. Access in: 10/31/2017

[5] W. Köeppen, Das Geographische System der Klimatologie, Berlin, 44 p. (1936)

[6] S. Simão, Fealq (1998) p. 760

[7] C.K. Yamaguchi, N.C. Turra, A.T.B. Strasser, Uniplac, 2 ed. (2016)

[8] FIESC. Available on: <http://fiesc.com.br/ sites/default/files/medias/sc_em_dados_ site_correto.pdf $>$. Accesso in 10/31/2017.

[9] H. Johnson, J. Robinson, Globo Estilo (2014) 